\title{
PERANAN DAN PEMANFAATAN RUANG PUBLIK PADA PERMUKIMAN KAMPUNG VERTIKAL RUSUN PEKUNDEN KOTA SEMARANG
}

\section{THE ROLE AND UTILIZATION OF PUBLIC SPACE AT PEKUNDEN RESIDENTIAL VERTICAL FLATS IN SEMARANG CITY}

\author{
Alif Bagoes Widiananda \\ Magister Pembangunan Wilayah dan Kota; Universitas Diponegoro, Semarang, Jawa Tengah; abw.nanda@yahoo.com \\ Info Artikel: \\ - Artikel Masuk: 13/03/18 \\ - Artikel diterima: 24/05/18 \\ - Tersedia Online: 28/02/18
}

\begin{abstract}
ABSTRAK
Pembaharuan kawasan perkotaan menjadi penting dalam usaha peremajaan kota sebagai solusi semakin berkurangnya ketersediaan lahan permukiman dalam perencanaan tata ruang kota yang baik. Langkah kebijakan Pemerintah kota Semarang dalam memenuhi upaya kebutuhan permukiman ini diwujudkan dengan membangun rumah susun. Rumah susun Pekunden yang berlokasi di tengah kota Semarang dibangun untuk merubah wajah kota sekaligus meningkatkan kualitas hunian dan mengembangkan kehidupan sosial budaya serta ekonomi penghuninya. Penelitian dilakukan untuk melihat peranan serta pemanfaatan dari ketersediaan ruang publik pada rusun Pekunden yang digunakan untuk interaksi para penghuni rusun dan juga masyarakat sekitarnya. Metode penelitian menggunakan cara deskriptif kuantitatif yang didapatkan dari hasil pengamatan serta responden objek penelitian. Hasil dari analisis penelitian ditemukan penggunaan ruang publik pada rusun Pekunden sudah cukup optimal yang dapat dilihat dari kontribusi peran dalam pemanfaatan ruang tersebut. Ruang ini dapat membentuk dan menghasilkan satu komunitas dinamis, memberikan keleluasaan bagi para penghuni untuk saling berinteraksi antar sesama mereka dan masyarakat lingkungan sekitarnya, serta memberikan dampak interaksi sosial bermasyarakat yang positif dalam lingkungan permukiman skala kota pada perkembangan kehidupan kota Semarang.

Kata Kunci : Permukiman; Rumah Susun; Ruang Publik
\end{abstract}

\section{ABSTRACT}

One of a solution to the diminishing availability of residential area in urban spatial planning is urban renewal. The Government of Semarang City make a policy to fulfilling efforts of the needs of this settlement is realized by build flats building. Pekunden flats which located in the middle of the city of Semarang was built to change the face of the city while improving the quality of dwelling and develop the socio-cultural and economic life of the inhabitants/resident. The research was conducted to see the role and utilization of public space availability in Pekunden flats which was used for the interaction of the resident and the surrounding/neighbourhood community. The research method using quantitative descriptive method obtained from the results of observations and respondents research object. The result of the research analysis has found that the public space in Pekunden flats is quite optimal which can be seen from the contribution of the role in the utilization of the public space. This space can form and produce a dynamic community, allowing the resident to interact with each other and the neighbourhood community and then make positive social interaction that impact on the environment city scale settlement in Semarang city lifes.

Keyword: Settlement; Flats; Public Space

Copyright $\odot 2016$ GJGP-UNDIP This open access article is distributed under a Creative Commons Attribution (CC-BY-NC-SA) 4.0 International license.

Cara men-sitasi (APA 6th Style):

Widiananda, Alif Bagoes., (2018). Peranan Dan Pemanfaatan Ruang Publik Pada Permukiman Kampung Vertikal Rusun Pekunden Kota Semarang. Jurnal Pembangunan Wilayah dan Kota, vol 14(1), 1 - 16

\section{PENDAHULUAN}

Pertumbuhan penduduk dan permukiman merupakan dua hal yang saling berkaitan, pertumbuhan jumlah penduduk pasti mempengaruhi kebutuhan rumah sebagai tempat untuk bermukim. Terkait dengan kebijakan Pemerintah yang diamanatkan pada UU No. 4 Tahun 1992 tentang Perumahan dan Permukiman, 
maka pembangunan rumah susun merupakan suatu respon serta solusi terhadap kebutuhan hunian bagi masyarakat pada lahan yang makin terbatas. Rumah susun bisa menjadi alternatif pilihan untuk penyediaan tempat tinggal yang ideal bagi negara-negara berkembang (Prasetyo, 2012). Menurut UU Nomor 20 Tahun 2011 menyatakan bahwa rumah susun adalah bangunan gedung bertingkat yang dibangun dalam suatu lingkungan yang terbagi dalam bagian yang distrukturkan secara fungsional, baik dalam arah horizontal maupun vertikal dan merupakan satuan yang dapat dimiliki dan digunakan secara terpisah, terutama untuk tempat hunian yang dilengkapi dengan bagian bersama, benda bersama, dan tanah bersama. Jauh sebelumnya pada masa Peraturan Pemerintah Nomor 4 Tahun 1988 juga menyatakan bahwa pembangunan rusun diarahkan untuk mempertahankan kesatuan komunitas kampung asal (terdahulu). Pembangunannya diprioritaskan pada lokasi di atas bekas kampung kumuh dan sasaran utamanya adalah penghuni kumuh itu sendiri yang mayoritas penduduknya berpenghasilan rendah. Penghuni rumah susun yang sebelumnya berasal dari para masyarakat kampung akan berusaha beradaptasi dengan lingkungan barunya, dari sebelumnya tinggal pada lahan horizontal kemudian berubah menjadi vertikal. Sesuai dengan pernyataan bahwa manusia juga ikut berkembang mengikuti perubahan didalam dirinya sendiri (Heimsath, 1988). Perkembangan ini termasuk dalam perkembangan sifat maupun perilaku mereka. Perilaku tiap manusia didalam lingkungan merupakan suatu proses interaksi antara dirinya dan juga lingkungan yang melibatkan motivasi dan kebutuhan-kebutuhan individual maupun sosial yang telah berkembang.

Kampung kota yang menjadi sebuah ciri dari permukiman padat penduduk memiliki tingkat ekonomi kelas menengah kebawah juga memiliki persamaan strata sosial yang menjadi salah satu aspek yang dapat menimbulkan rasa kebersamaan dan kekeluargaan erat. Aktivitas sosial budaya yang erat ini tidak dapat kesampingkan dan dipisahkan, sehingga kampung dan penduduknya seakan menjadi sebuah satu kesatuan (Suminar, 2016). Rusun yang merupakan transformasi dari kampung vertikal merupakan konsep hunian pada wilayah tertentu yang didominasi oleh masyarakat berpenghasilan menengah kebawah, dimana bangunannya didirikan tegak lurus dari bawah ke atas (Sutungpol, 2013). Kota Semarang merupakan salah satu kota yang mengalami perkembangan cukup pesat. Kondisi ini ditandai dengan laju pertumbuhan penduduk yang meningkat, hal ini dibuktikan dengan jumlah penduduk yang mencapai 1.591 .860 jiwa dengan laju pertumbuhan mencapai 0,59\% pada tahun 2015 (Semarang Dalam Angka 2016). Dalam jangka waktu 5 (lima) tahun terakhir (2011-2015), perkembangan kepadatan penduduk kota Semarang cenderung naik seiring dengan kenaikan jumlah penduduknya. Pembaharuan kawasan perkotaan merupakan salah satu bentuk usaha peremajaan kota (urban renewal) sebagai solusi perencaanaan tata ruang yang baik. Hal ini dituangkan pada Peraturan Daerah kota Semarang yang terbaru nomor 14 tahun 2011 tentang Rencana Tata Ruang Wilayah (RTRW) Kota Semarang Tahun 2011-2031 yang menyebutkan rencana pengembangan kawasan perumahan pada wilayah dengan kepadatan yang tinggi di kota Semarang salah satunya melalui peningkatan kualitas hunian kawasan perumahan dengan pembangunan secara vertikal (rumah susun/apartemen).

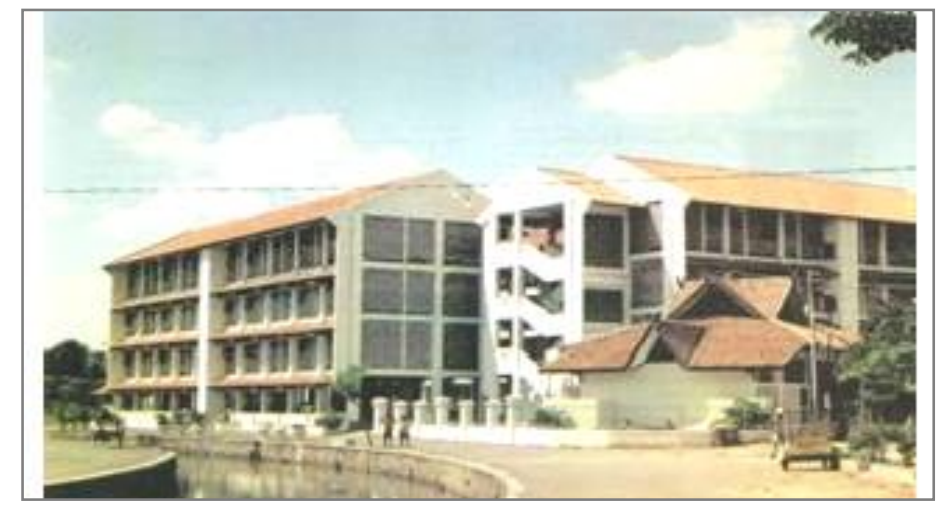

Gambar 1. Awal Berdiri Rusun Pekunden (Dokumentasi DTKP kota Semarang, 1992) 
Lahir dari solusi wadah bermukim yang baru sebagai urban renewal, rusun Pekunden muncul sebagai fenomena berkonsep kampung vertikal yang menyediakan hunian ditengah kota yang padat penduduk (lihat Gambar 1). Daerah sekitar rusun merupakan daerah permukiman yang padat serta berada disekitar kompleks perkantoran dan perdagangan jasa karena letaknya berada di pusat kota Semarang. Diharapkan dengan tersedianya bangunan ini, hubungan bermasyarakat antara warga penghuni rusun serta warga sekitar kompleks rusun dapat terjalin dengan baik. Warna kehidupan / corak khas warga kampung sengaja tetap dipertahankan seperti rasa kebersamaan, kekeluargaan, serta guyub dalam bersosialisasi. Dalam mengakomodasi berbagai aktivitas sosialisasi bersama para penghuni disediakan fasilitas ruang publik. Ruang publik merupakan ruang sosial menjadi salah satu kebutuhan pokok para penghuni untuk mengembangkan kehidupan bermasyarakat (Wellman, 1979). Ruang ini merupakan media interaksi bersama antar anggota komunitas dan lingkungannya, dimana dapat menimbulkan rasa kebersamaan (keguyuban) karena pemanfaatannya yang tidak hanya bersifat pribadi. Ruang publik juga berfungsi sebagai suatu wadah yang dapat menampung berbagai kegiatan kebersamaan bermasyarakat (baik positif atau negatif) didalam memenuhi kebutuhan ekonomi/sosial/budaya warga (Darmiwati, 2000).

Ruang publik menjadi pusat interaksi sosial yang dilakukan semua lapisan masyarakat, digunakan dalam melayani kebutuhan sosial dan memberikan pengetahuan kepada para pelakunya. Ruang ini menjadi ruang milik bersama dan tempat masyarakat melakukan aktivitas fungsional serta ritualnya dalam suatu ikatan komunitas, baik kehidupan sehari-hari maupun dalam perayaan berkala, tempat masyarakat melakukan aktivitas individu dan aktivitas berkelompok (Carr, 1992). Ruang publik dapat menampung aktivitas tertentu dari masyarakat yang tinggal didalamnya, baik secara individu maupun kelompok dan dapat memberikan karakter tersendiri serta memiliki fungsi interaksi sosial bagi masyarakat, ekonomi rakyat, dan apresiasi budaya (Darmawan, 2009). Pemanfaatan ruang publik mempunyai beberapa faktor yang saling berkaitan antara lain: faktor individu, faktor sosial, faktor lingkungan, dan faktor kebijakan (Jacinta, 2012). Sedangkan pemanfaatan ruang publik lainnya dapat dilihat dari faktor pengguna yang dijabarkan dalam karakteristik usia, status perkawinan, jumlah anggota keluarga yang dimiliki, tingkat pendidikan, tingkat pendapatan, dan lama tinggal (Farida, 2013). Untuk faktor fisik dapat dilihat dari faktor lokasi dan tata letak (aksesibilitas) ruang publik tersebut dalam kemudahan pencapaian. Keberadaan objek menarik juga ikut membantu peluang kegiatan sosial dilakukan pada lingkungan tersebut serta dengan adanya ketersediaan vegetasi guna mendukung aktivitas interaksi publik. Jadi pada dasarnya perilaku pemanfaatan ruang publik pada kompleks rumah susun harus dapat membentuk karakter penghuninya menjadi satu komunitas yang dinamis dan dapat memberi keleluasaan penghuni untuk saling berkomunikasi satu sama lainnya.

Pada rusun Pekunden, peranan ruang publik sebagai refleksi kebutuhan dapat dilihat dari aktivitas sosial budaya maupun ekonomi, misalnya terdapat keunikan berupa informal activity yang terjadi pada ruang publik tersebut. Kemudian, keberadaan ruang publik yang ada pada kompleks rusun sebagian telah terjadi beberapa masalah serta tidak optimal dalam penggunaan dan pemanfaatannya. Disekitar kawasan rusun Pekunden juga masih terdapat permukiman warga yang padat tanpa diimbangi dengan tersedianya prasarana lingkungan yang memadai, sehingga dalam prakteknya banyak warga sekitar yang ikut masuk untuk beraktivitas bersama menggunakan fasilitas ruang publik yang ada didalam rusun. Oleh karena itu, peranan ruang publik rusun Pekunden menjadi sangat perlu untuk diperhatikan. Terkait beberapa uraian penjelasan diatas, maka penelitian ini dimaksudkan untuk mengidentifikasi dan menganalisis peranan dan pemanfaatan ruang publik yang menjadi salah satu fasilitas rumah susun Pekunden yang digunakan sebagai media aksesibilitas, sosial budaya, maupun ekonomi. Dan juga untuk melihat sejauh mana pengaruh keberadaan ruang publik yang ada di rusun Pekunden ini bagi lingkungan wilayah disekitarnya. Diharapkan penelitian ini dapat memberikan manfaat berupa gambaran penyediaan rusun dengan penerapan layak huni yang nyaman, meningkatkan kualitas hunian yang ideal, dilengkapi dengan ruang publik secara optimal serta dapat digunakan secara bersama-sama para warganya. 


\section{DATA DAN METODE}

\subsection{Metode Penelitian}

Pendekatan penelitian menggunakan pendekatan positivistik dengan cara deduktif. Pendekatan positivistik digunakan untuk melihat kejadian fakta/kenyataan yang ada pada rusun Pekunden seperti fenomena pemanfaatan ruang publik yang digunakan oleh para penghuni dan masyarakat sekitarnya. Pendekatan ini mengandalkan kemampuan pengamatan peneliti secara langsung dengan memandang realitas/gejala/fenomena yang ada. Cara deduktif yaitu penelitian dilakukan berdasarkan teori literatur yang telah ada sebelumnya tentang rumah susun dan penggunaan ruang publik untuk mendukung dan memperkuat hasil penelitian yang didapatkan dari data lapangan yang telah dikumpukan.

Teknik pengambilan sampel pada penelitian ini menggunakan teknik probability sampling dan nonprobability sampling. Probability sampling adalah teknik pengambilan sampel yang memberikan peluang yang sama kepada setiap unsur anggota populasi untuk dipilih menjadi anggota sampel. Sedangkan nonprobability sampling adalah teknik pengambilan sampel yang tidak memberikan peluang yang sama kepada setiap unsur anggota populasi untuk dipilih menjadi anggota sampel (Sugiyono, 2010). Pada teknik probability sampling, teknik yang digunakan adalah Stratified Random Sampling (untuk keperluan sampel kuesioner), dimana teknik ini digunakan bila terdapat anggota/unsur yang tidak homogen dan juga berstrata (bertingkat/berlapis) secara proporsional yang ada didalam populasi tersebut, misalnya pada pembagian wilayah RT yang dibedakan menurut tata letak unit hunian rumah susun pada tiap lantainya karena setiap lantai memiliki kepengurusan RT yang berbeda pula. Sistem sampling menggunakan rumus Slovin untuk menyaring jumlah dari responden kuesioner. Untuk teknik non-probablity sampling yang dipergunakan adalah purposive sampling (untuk keperluan sampel wawancara), karena dipilih secara sengaja berdasarkan beberapa kriteria dari narasumber yang telah tercukupi syaratnya untuk menjadi narasumber dalam pengambilan sampel, serta dengan menggunakan teknik aksidental sampling pada para pelaku pengunjung yang beraktivitas didalam wilayah ruang publik rusun Pekunden.

Penelitian ini menggunakan metode teknik analisis deskriptif kuantitatif yaitu, menggunakan wujud data kombinasi angka yang dimasukan kedalam tabel dan disertai grafik data yang memberikan deskripsi atau penjelasan gambaran secara sistematis, faktual, dan akurat dari hasil penelitian rusun Pekunden seperti analisis karakteristik penghuni, analisis kegiatan perkumpulan warga, dan analisis fisik lingkungan serta pemanfaatan ruang publik. Metode deskriptif ini dipakai ketika meneliti status sekelompok manusia, suatu objek, suatu sistem pemikiran ataupun suatu kelas peristiwa pada masa sekarang (Nazir, 2013).

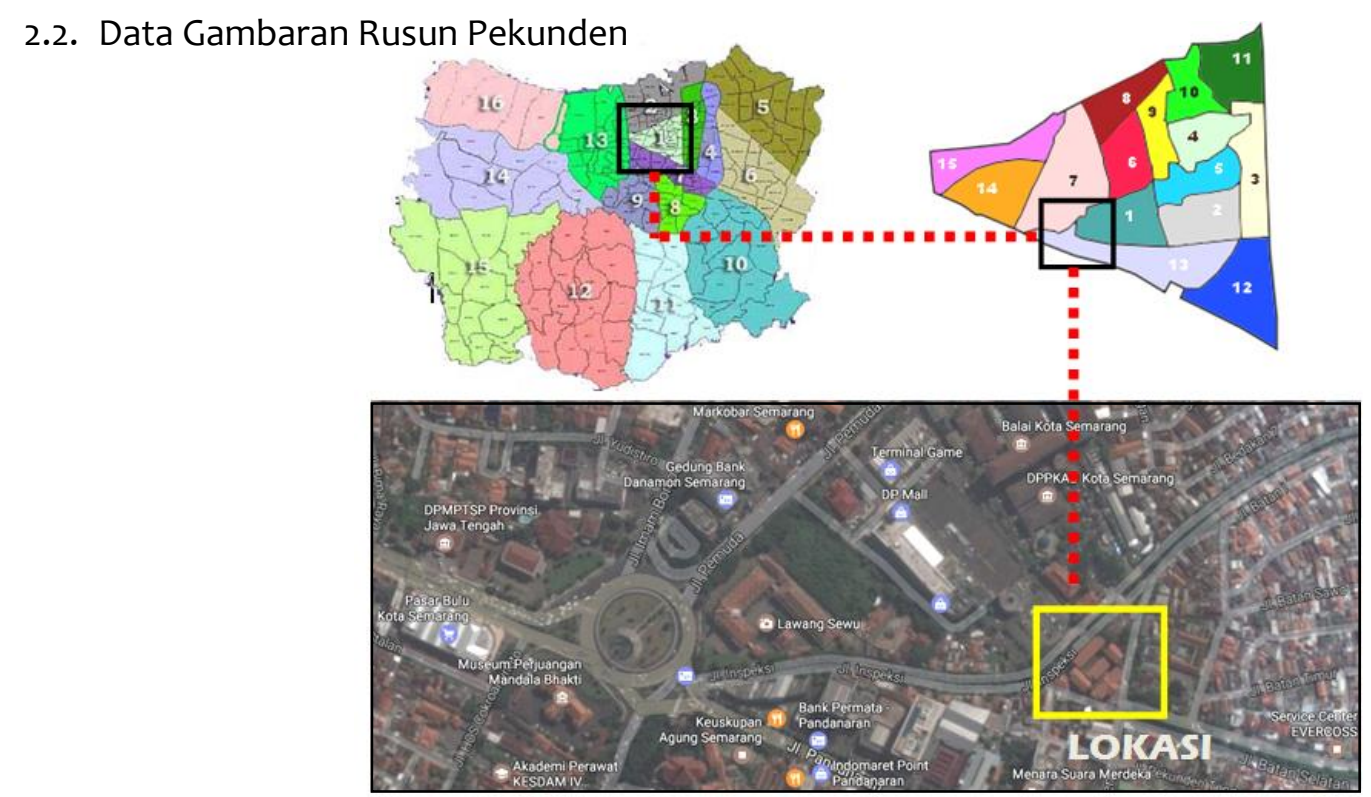

Gambar 2. Peta Kota Semarang Terhadap Lokasi Rusun Pekunden (Google Maps, 2017) 
Penelitian ini berlokasi pada Kelurahan Pekunden, Kecamatan Semarang Tengah seperti terlihat pada Gambar 2 diatas. Lokasi ini berada pada daerah BWK-I (Batas Wilayah Kota) Semarang yang strategis untuk aktivitas permukiman/perumahan, perkantoran, jasa, dan perdagangan. Luas lahan rusun Pekunden sekitar $3.889 \mathrm{~m} 2$ dengan luas bangunan mencapai $2.835 \mathrm{m2}$. Rusun ini dibangun tahun 1990 dan selesai pada 1992. Terdiri dari 5 (lima) blok tower dengan tinggi 4 (empat) lantai. Jumlah unit hunian sebanyak 88 unit, yang terdiri dari T-27, T-54, dan T-81.

Suasana lingkungan sekitar Rusun Pekunden terdapat beberapa bangunan disekitar rusun Pekunden antara lain, kantor Balaikota Semarang, kantor BPS Semarang, Lawang Sewu, DP Mall, Menara Suara Merdeka, RS Hermina, Aston Inn Hotel. Ada juga pusat jajanan kuliner disepanjang Jl. Batan Selatan berupa tenda PKL yang dibangun oleh pemkot. Dengan hadirnya kompleks rusun Pekunden menimbulkan dampak ekonomi dengan muncul beberapa titik PKL berdagang serta UKM disekitar kawasan rusun yang mengundang warga sekitar untuk beraktivitas di wilayah tersebut seperti yang ditampilkan pada Gambar 3 . Beberapa pelaku usaha membuka usaha seperti warung makan, kios kelontong, counter handphone, counter majalah, kios salon, agen air isi ulang, laundry pakaian, bengkel motor, foto studio, serta café.
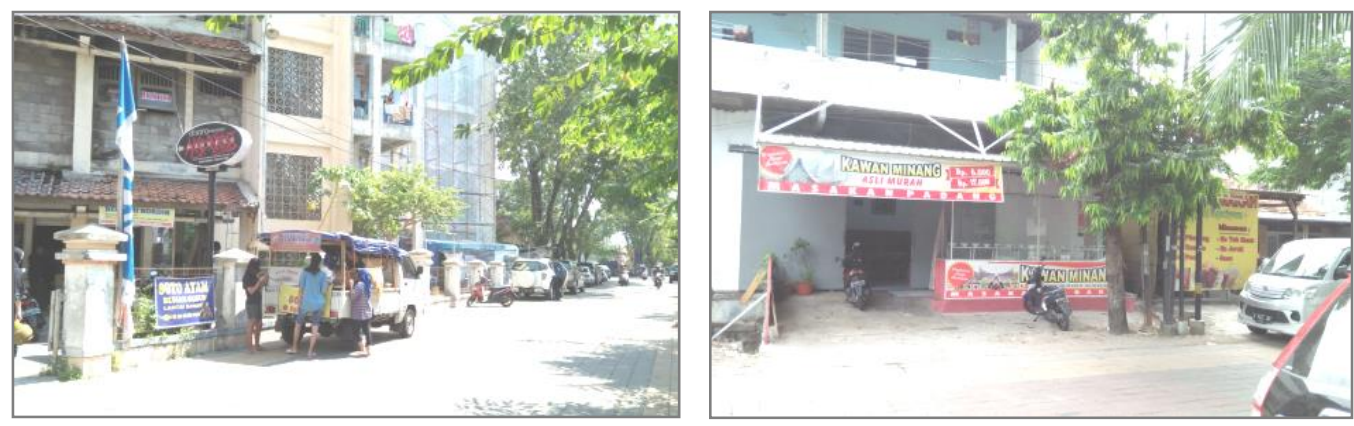

Gambar 3. Lingkungan Sekitar Rusun Pekunden (Observasi Lapangan, 2017)

Pada masa perencanaan rusun ini melibatkan kolaborasi antara pemerintah, para tenaga ahli, dan juga partisipasi aktif dari masyarakat sebagai calon penghuninya. Rumah susun Pekunden direncanakan sebagai rumah susun sederhana sewa, namun sebanyak 50 unit hunian (lihat pada Gambar 4) ditempati oleh warga kampung setempat atau pewarisnya sebagai kompensasi dampak penggusuran (proyek peremajaan kota) tempat tinggal mereka sebelumnya yang berada pada lokasi rusun terbangun. Sisanya sebanyak 38 unit hunian disewakan dan dikelola UPTD rumah sewa dari sub-unit DTKP kota Semarang.

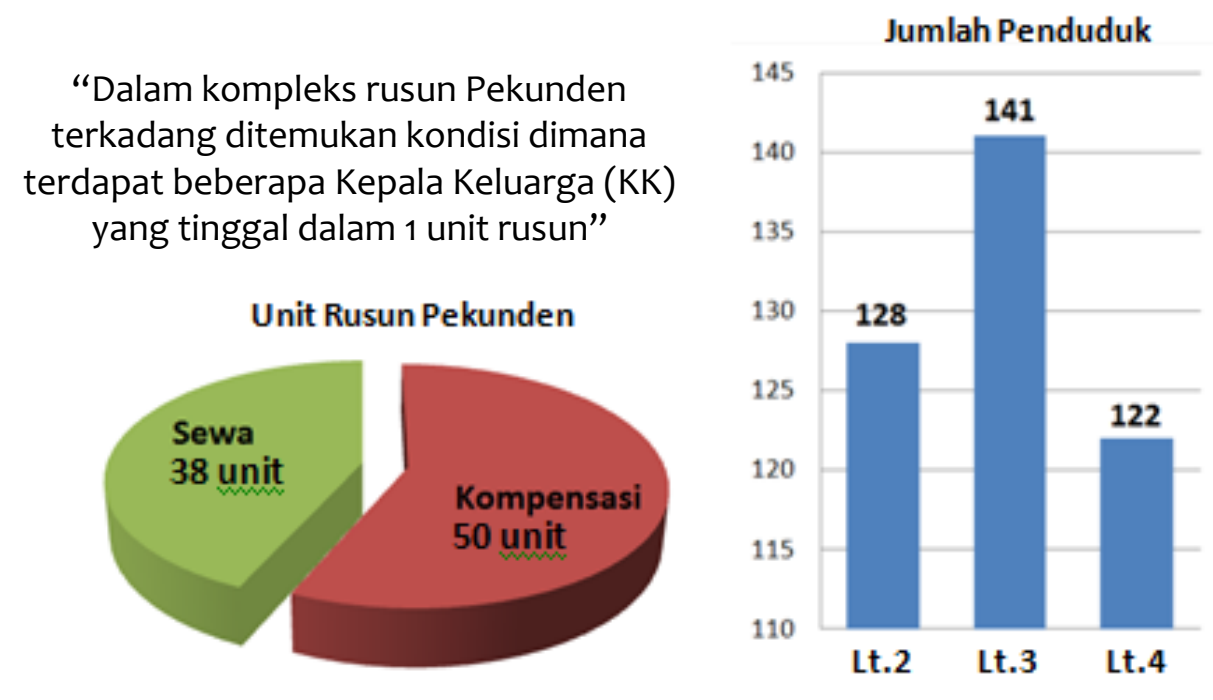

Gambar 4. Unit Rusun dan Jumlah Penduduk (Observasi Lapangan, 2017) 
Pembagian zona hunian dilakukan pada blok bangunan rusun. Ini dilakukan untuk memudahkan identifikasi warga penghuni rusun. Unit hunian kompensasi diletakkan pada lantai 2 hingga sebagian lantai 3 pada setiap blok bangunan. Sedangkan untuk unit hunian sewa diletakkan pada sebagian lantai 3 dan juga pada lantai 4 pada setiap blok bangunan. Total penghuni rusun sebanyak 391 jiwa dari $116 \mathrm{KK}$. Suasana hunian pada kompleks rusun Pekunden dapat dilihat pada Gambar 5 dibawah ini.
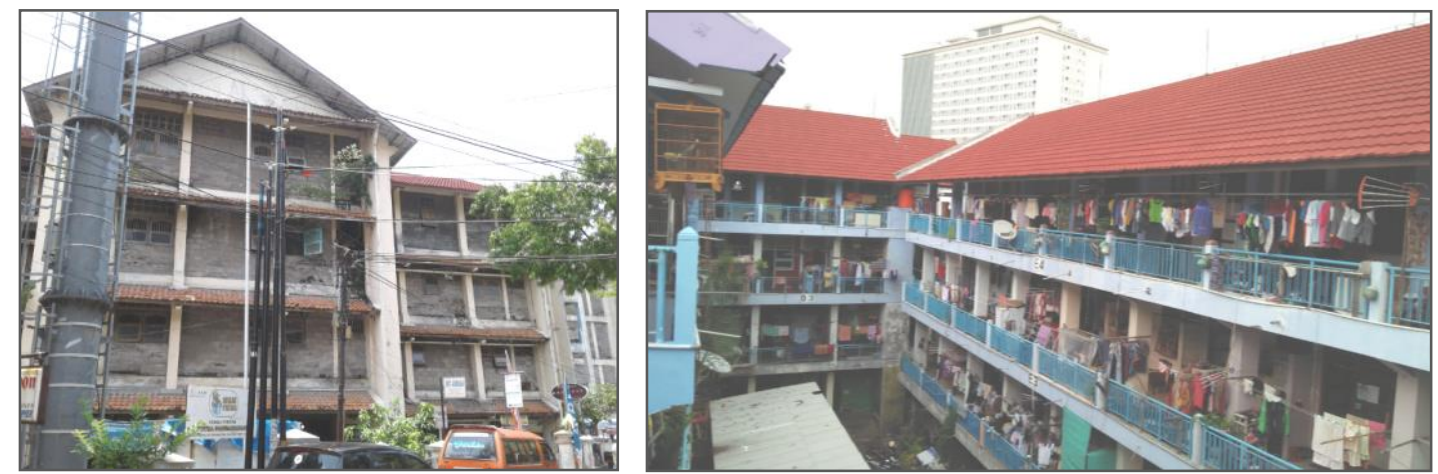

Gambar 5. Suasana Hunian Rusun Pekunden (Observasi lapangan, 2017)

\section{HASIL DAN PEMBAHASAN}

Pembahasan penelitian berfokus pada ruang publik yang ada di rusun Pekunden. Ruang publik ini dibagi menjadi 2 yaitu full public dan semi private. Pembagian ini dilakukan karena para pelaku yang beraktivitas didalam ruang publik rusun Pekunden tidak hanya sebatas penghuninya saja, namun juga terdapat pengunjung yang ikut memanfaatkan ruang publik tersebut. khusus pada bagian semi private tidak bisa diakses secara bebas oleh orang luar karena berada pada zona hunian yang memerlukan privasi. Ruang yang bersifat semi private seperti teras selasar hunian, selasar penghubung, hall tiap lantai, dan aula pertemuan. Untuk ruang yang bersifat full public tersedia pada taman aktif, lapangan olahraga, kios sewa pasar krempyeng, dan lapangan parkir kendaraan. Berbagai analisa dilakukan untuk meneliti peranan serta pemanfaatan dari ruang publik yang ada pada rusun Pekunden tersebut.

3.1. Analisis Karakteristik Penghuni

1) Durasi lama tinggal

Durasi lama tinggal berpengaruh membentuk pandangan/persepsi dalam beraktivitas didalam ruang publik. Biasanya semakin lama tinggal didalam suatu kompleks maka rasa memanfaatkan berbagai fasilitas yang ada akan tumbuh, dalam hal ini juga termasuk dalam memanfaatkan ruang publik yang ada dan tersedia di rusun. Hasil data kuesioner tersaji pada Tabel 1 berikut:

Tabel 1. Lama Tinggal Penghuni Rusun (Observasi Lapangan, 2017)

\begin{tabular}{|c|c|c|}
\hline Durasi & Jumlah & Persen (\%) \\
\hline$<1$ Tahun & 2 & 3.70 \\
\hline 2-5 Tahun & 7 & 12.96 \\
\hline 5-10 Tahun & 14 & 25.93 \\
\hline > 10 Tahun & 31 & 57.41 \\
\hline Jumlah KK & 54 & 100 \\
\hline
\end{tabular}

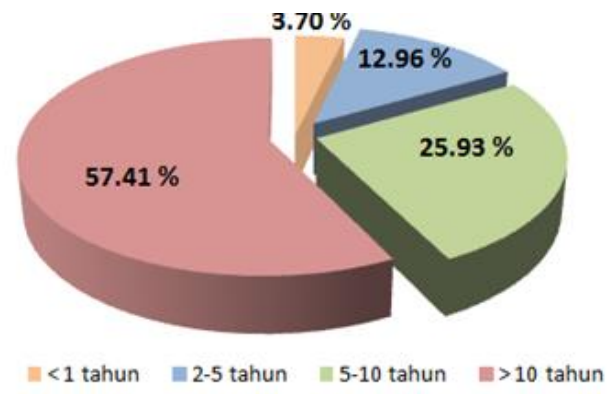

2) Usia penghuni

Bila dilihat dalam rentang usia maka hal ini berkaitan dengan pengalaman individu seseorang dalam belajar, kemampuan, dan kematangan (Sjafari, 2014). Artinya faktor usia penghuni dapat 
mempunyai potensi dalam membentuk persepsi atau pandangan ketika beraktivitas di ruang publik, karena bila berbeda usia maka biasanya akan berbeda pula kepentingan dan pandangan dalam kegiatan beraktivitasnya. Hasil data kuesioner tersaji pada Tabel 2 berikut:

Tabel 2. Usia Penghuni Rusun (Observasi Lapangan, 2017)

\begin{tabular}{|c|c|c|}
\hline Rentang & Jumlah & Persen (\%) \\
\hline $17-24$ & - & 0 \\
\hline $25-34$ & 3 & 7.41 \\
\hline $35-44$ & 7 & 12.96 \\
\hline$>45$ & 43 & 79.63 \\
\hline Total & 54 & 100 \\
\hline
\end{tabular}

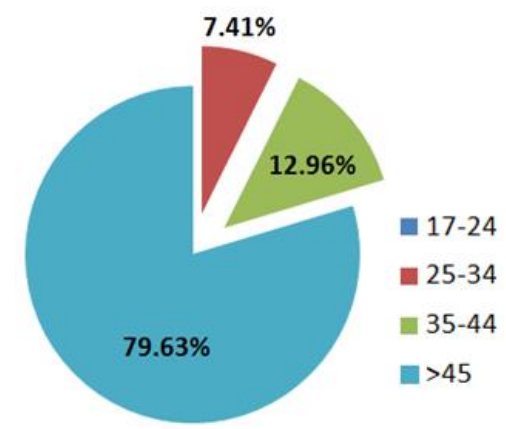

3) Populasi anggota keluarga

Jumlah penghuni pada setiap hunian dapat memberikan dampak penggunaan ruang publik sebagai media interaksi antar warga penghuni rusun. Semakin banyak warga penghuni, peluang untuk optimalisasi penggunaan ruang publik juga akan semakin besar. Bila semakin banyak jumlah anggota keluarga dalam satu rumah/unit hunian maka kebutuhan ruang akan semakin tinggi. Hasil data kuesioner tersaji pada Tabel 3 berikut:

Tabel 3. Populasi Anggota Keluarga (Observasi Lapangan, 2017)

\begin{tabular}{|c|c|c|}
\hline $\begin{array}{c}\text { Jumlah Anggota } \\
\text { Keluarga }\end{array}$ & Jumlah KK & Persen (\%) \\
\hline 1 & 3 & 5.56 \\
\hline 2 & 7 & 12.96 \\
\hline 3 & 11 & 20.37 \\
\hline 4 & 18 & 33.33 \\
\hline 5 & 10 & 18.52 \\
\hline$>6$ & 5 & 9.26 \\
\hline Total & 54 & 100 \\
\hline
\end{tabular}

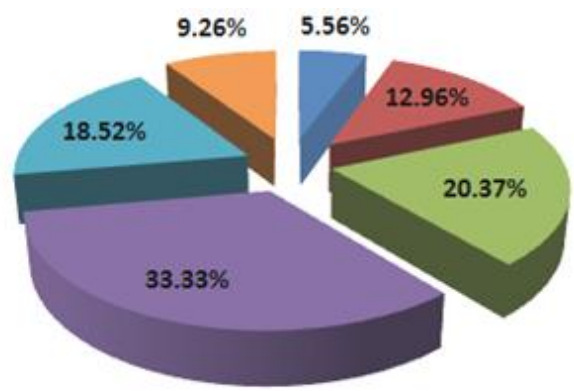

4) Tingkat pendidikan

$=1 \pm 2=3=4=5 \|>6$

Tingkat pendidikan mengindikasikan gambaran pendidikan terakhir yang ditempuh oleh warga penghuni rusun Pekunden. Tingkat pendidikan ini kerap erat berkaitan dengan tingkat pendapatan karena dapat mengindikasikan status sosial ekonomi yang menjadi salah satu indikator yang berpengaruh dalam interaksi sosial (Farida, 2013). Hasil data kuesioner tersaji pada Tabel 4 berikut:

Tabel 4. Tingkat Pendidikan (Observasi Lapangan, 2017)

\begin{tabular}{|c|c|c|}
\hline Status Pendidikan & Jumlah & Persen (\%) \\
\hline Tamat SD & 8 & 14.81 \\
\hline Tamat SMP & 15 & 27.78 \\
\hline Tamat SMA & 26 & 48.15 \\
\hline Tamat PTN/PTS & 5 & 9.26 \\
\hline Total & 54 & 100 \\
\hline
\end{tabular}

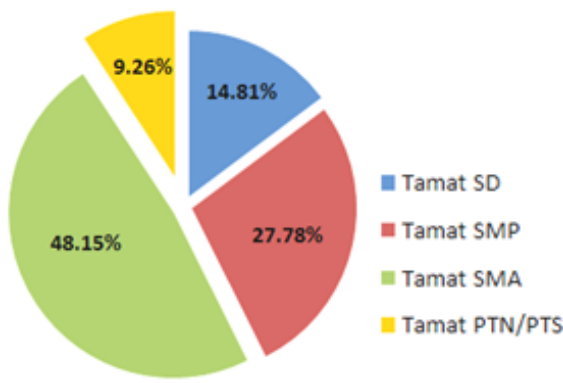


5) Jenis pekerjaan

Data dari jenis pekerjaan memperlihatkan berbagai profesi pekerjaan yang menjadi mata pencaharian para warga penghuni rusun Pekunden. Terdapat beberapa variasi pekerjaan dari para kepala keluarga, namun tetap didominasi pekerjaan sebagai karyawan swasta. Hasil data kuesioner tersaji pada Tabel 5 berikut:

Tabel 5. Jenis Pekerjaan (Observasi Lapangan, 2017)

\begin{tabular}{|c|c|c|}
\hline Status & Jumlah & Persen (\%) \\
\hline PNS/TNI/Polri & 5 & 9.26 \\
\hline Wirausaha & 10 & 18.52 \\
\hline Karyawan swasta & 30 & 55.56 \\
\hline Buruh & 3 & 5.56 \\
\hline Pensiunan & 6 & 11.11 \\
\hline Total & 54 & 100 \\
\hline
\end{tabular}

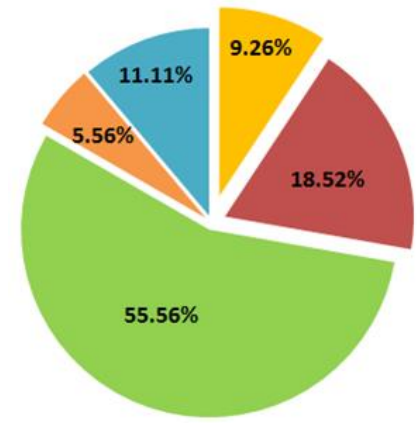

- PNS/TNI/Polri

naryawan swasta

Eensiunan

wirausaha

Buruh

6) Tingkat pendapatan

Tingkat pendapatan memberikan gambaran tentang kondisi ekonomi para penghuni rusun. Terbagi menjadi empat bagian klasifikasi tingkat pendapatan hasil dari pengamatan yang dilakukan. Pembagian berdasarkan segi finansial yang diukur dari tingkat pendapatan masing-masing KK penghuni rusun. Data ini diambil dari responden penghuni rusun sebanyak 54 KK. Hasil data kuesioner tersaji pada Tabel 6 berikut:

Tabel 6. Tingkat Pendapatan (Observasi Lapangan, 2017)

\begin{tabular}{|c|c|c|}
\hline Pendapatan & Jumlah & Persen (\%) \\
\hline < Rp.1.000.000 & 5 & 9.26 \\
\hline Rp. $1.000 .000-$ Rp.2.000.000 & 33 & 61.11 \\
\hline Rp. 2.000.000 - Rp.3.000.000 & 10 & 18.52 \\
\hline > Rp.3.000.000 & 6 & 11.11 \\
\hline Total & 54 & 100 \\
\hline \multicolumn{3}{|c|}{$\|<\operatorname{Rp} .1 .000 .000$} \\
\hline
\end{tabular}

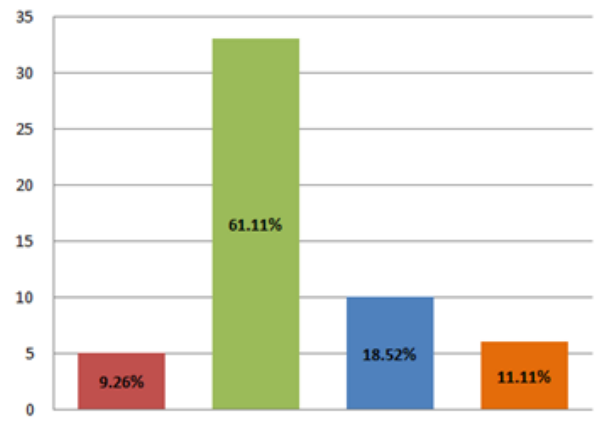

\subsection{Analisis Kegiatan Perkumpulan Warga}

Rumah susun didesain saling berdekatan satu sama lain guna memudahkan interaksi antar sesama warga penghuni. Untuk mengetahui interaksi para warga penghuni, bisa dilakukan dengan meneliti kegiatan yang dilakukan seperti jumlah partisipasi warga dalam mengikuti berbagai kegiatan perkumpulan yang ada dan juga sejauh mana keaktifan para warga penghuni dalam menghadiri suatu kegiatan jika dilihat dari frekuensi hadirnya dalam kegiatan tersebut. Semakin sering frekuensi pertemuan tersebut, semakin berfungsi ruang-ruang pertemuan tersebut digunakan.

Beberapa jenis kegiatan perkumpulan yang menjadi partisipasi dari warga penghuni rusun Pekunden antara lain sebagai berikut:
a. Perkumpulan RT
d. Karang taruna
g. PKK/Dasawisma
b. Perkumpulan Blok
e. Remaja masjid
h. PAUD
c. Posyandu
f. Pengajian rutin
i. Kerja bakti lingkungan

Berbagai jenis perkumpulan warga yang terjadi di kompleks rusun menjadi bukti keaktifan para penghuninya. Namun, tidak semua perkumpulan tersebut kerap diikuti setiap warganya. Disini kita dapat melihat seberapa banyak jumlah kegiatan yang diikuti oleh tiap warga penghuni di kompleks rusun Pekunden (lihat pada Tabel 7), karena otomatis setiap warga penghuni berbeda dalam mengikuti perkumpulan warga satu dengan perkumpulan warga lainnya. 
Semua kegiatan berakibat pada pemanfaatan ruang publik sebagai media bertemu dan berkumpulnya berbagai jenis kegiatan yang dilakukan oleh para warganya. Dengan demikian, ruang publik menjadi hal yang dibutuhkan dan bermanfaat dalam mempersatukan berbagai kegiatan tersebut.

Tabel 7. Jumlah Partisipasi Perkumpulan (Sumber: Observasi Lapangan, 2017)

\begin{tabular}{|c|c|c|}
\hline $\begin{array}{c}\text { Jumlah } \\
\text { Kegiatan }\end{array}$ & Jumlah KK & Persen (\%) \\
\hline 1 & 2 & 3.70 \\
\hline 2 & 4 & 7.41 \\
\hline 3 & 14 & 25.93 \\
\hline 4 & 18 & 33.33 \\
\hline 5 & 11 & 20.37 \\
\hline$>5$ & 5 & 9.26 \\
\hline TOTAL & 54 & 100 \\
\hline
\end{tabular}

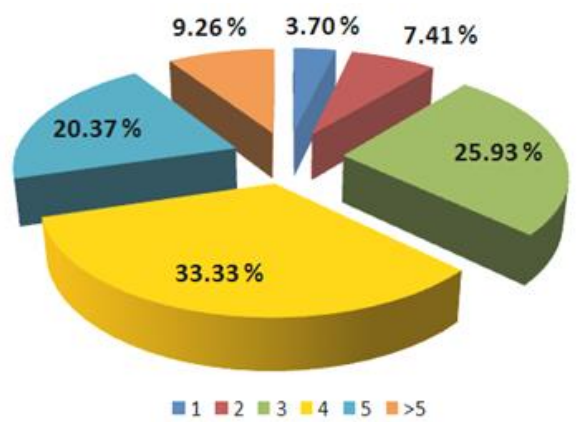

Tabel 8. Jumlah Frekuensi Keaktifan (Observasi Lapangan, 2017)

\begin{tabular}{|c|c|c|}
\hline Keterangan & $\begin{array}{c}\text { Jumlah } \\
\text { KK }\end{array}$ & Persen (\%) \\
\hline Selalu hadir & 40 & 74.07 \\
\hline Kadang-kadang & 14 & 25.93 \\
\hline Tidak pernah & 0 & 0 \\
\hline Total & 54 & 100 \\
\hline
\end{tabular}

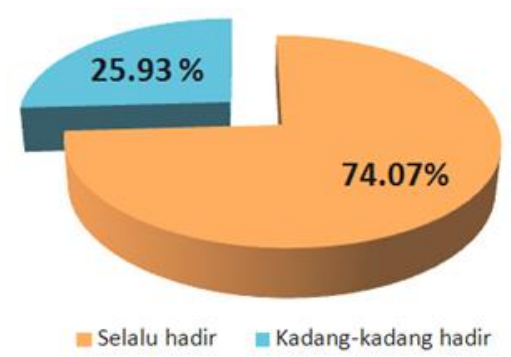

3.3. Analisis Fisik Lingkungan \& Pemanfaatan Ruang Publik

1) Teras selasar hunian

Berada didepan unit hunian dan disepanjang koridor tiap blok massa bangunan rusun (lihat Gambar 6) pada lantai 2 hingga lantai 4 sehingga mempunyai akses pencapaian yang sangat mudah dikarenakan letaknya yang berada di kawasan hunian rusun. Area ini merupakan area semi private yang tidak bebas diakses siapa saja karena khusus diperuntukkan untuk hunian para penghuni rusun. Biasanya digunakan untuk area kegiatan serta interaksi penghuni. Kegiatan seperti duduk santai, mengobrol dengan tetangga, menjemur pakaian, meletakkan barang-barang, dll.
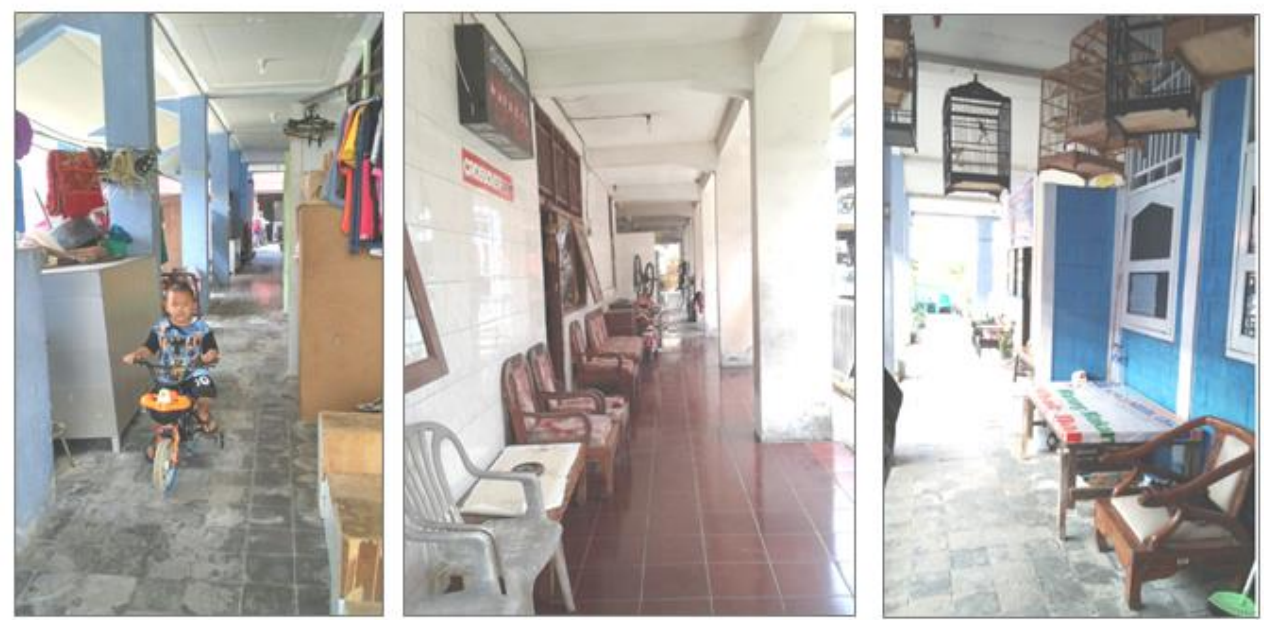

Gambar 6. Suasana Teras Selasar Hunian (Observasi Lapangan, 2017) 
Beberapa jenis kegiatan yang biasa dilakukan para penghuni unit rusun dan intensitas penggunaan dalam waktu seminggu pada aktivitas yang berada di teras selasar hunian dapat dilihat seperti yang tersaji pada Gambar 7 dari data hasil kuesioner responden berikut:
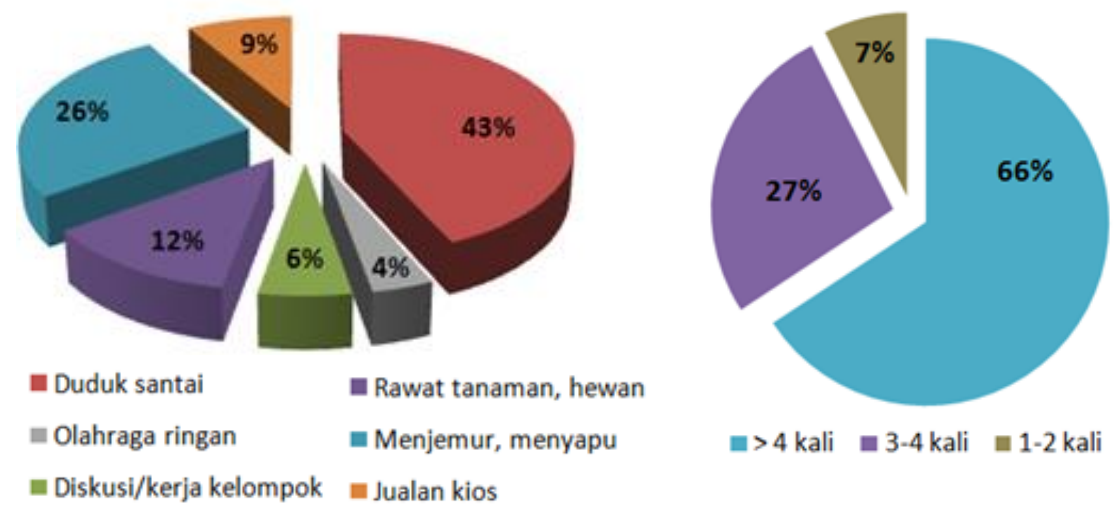

Gambar 7. Grafik Jenis Kegiatan dan Intensitas Penggunaan Pada Teras Selasar Hunian (Observasi Lapangan, 2017)

2) Selasar penghubung

Berada pada setiap lantai blok bangunan hunian (lihat Gambar 8) lantai 2 hingga lantai 4 yang berfungsi menghubungkan antara blok massa bangunan. Akses pencapaian tergolong mudah karena berada dekat di kawasan hunian. Selasar ini juga termasuk area semi private yang tidak bebas diakses. Terkadang area ini dapat digunakan aktivitas seperti: merawat hewan peliharaan, menjemur pakaian/makanan, mengobrol, dan olahraga kecil.
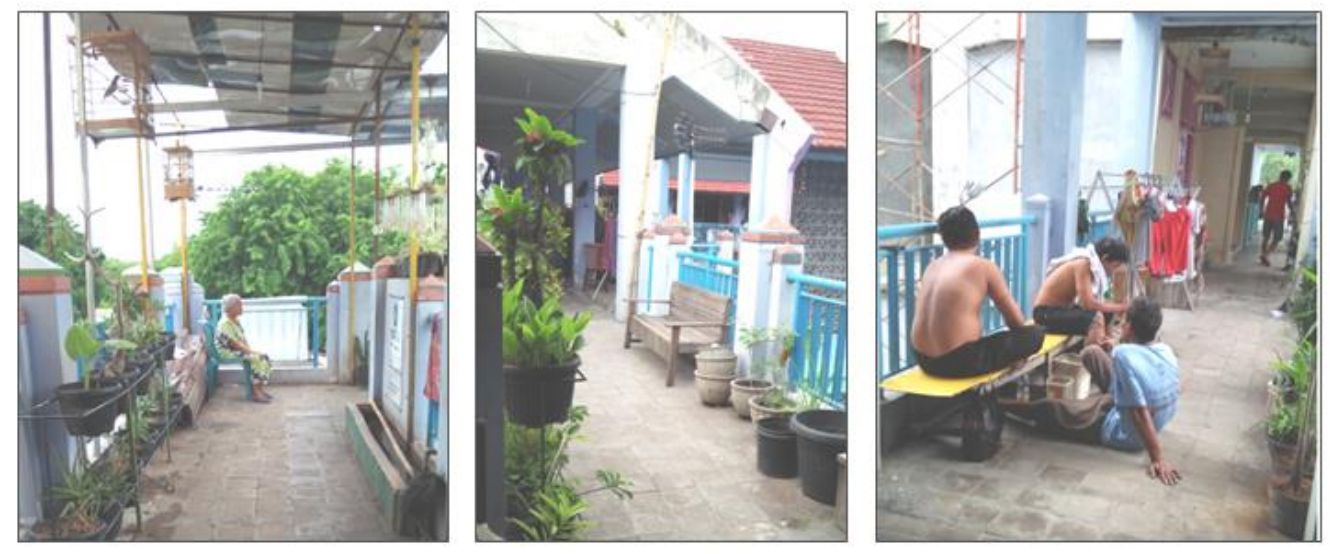

Gambar 8. Suasana Selasar Penghubung (Observasi Lapangan, 2017)

Beberapa jenis kegiatan yang dilakukan dan intensitas penggunaan dalam waktu seminggu pada aktivitas selasar penghubung dapat dilihat seperti yang tersaji pada Gambar 9 dari data hasil kuesioner responden berikut: 


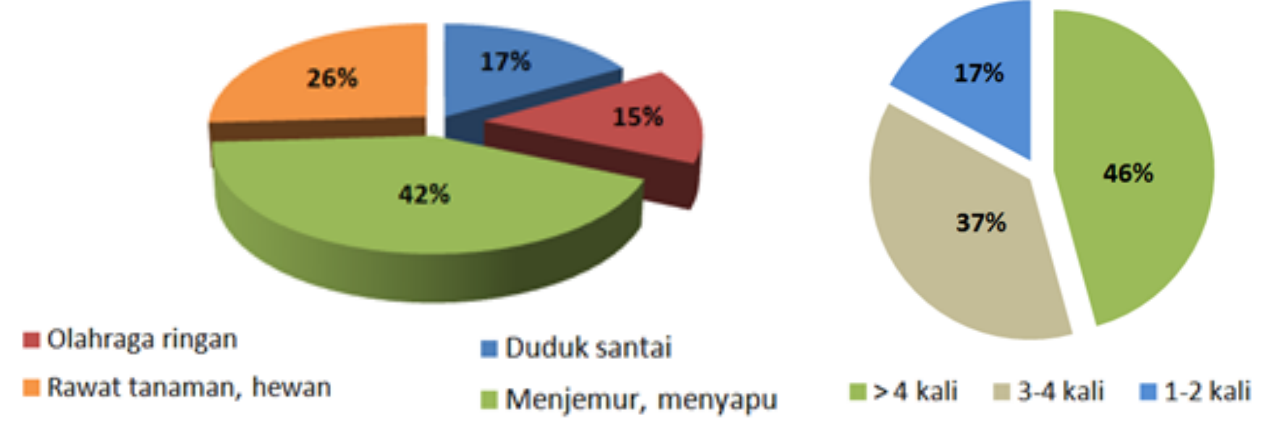

Gambar 9. Grafik Jenis Kegiatan dan Intensitas Penggunaan Pada Selasar Penghubung

3) Hall tiap lantai

(Observasi Lapangan, 2017)

Terletak di bangunan rusun blok A pada lantai 2 hingga lantai 4 yang merupakan ruang terbuka dan digunakan warga penghuni untuk tempat berkumpul serta agenda berbagai acara pertemuan RT dengan luasan $72 \mathrm{~m}^{2}$ cukup untuk menampung warga. Area ini termasuk area semi private yang tidak bebas diakses oleh orang lain.

Beberapa jenis kegiatan yang dilakukan dan intensitas penggunaan dalam waktu seminggu pada aktivitas hall tiap lantai dapat dilihat seperti yang tersaji pada Gambar 10 dari data hasil kuesioner responden berikut:
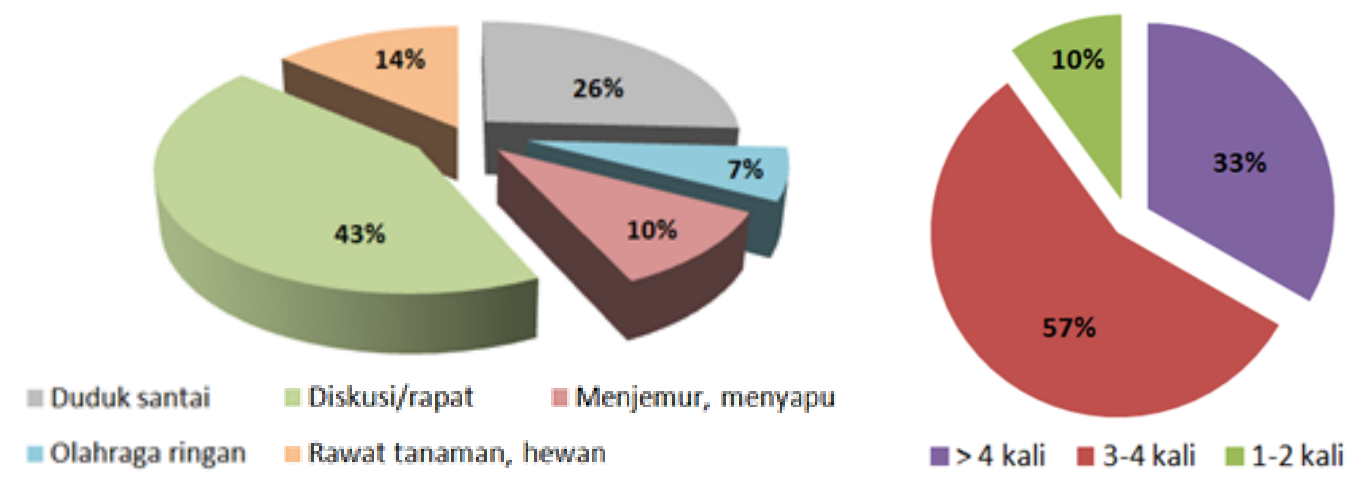

Gambar 10. Grafik Jenis Kegiatan dan Intensitas Penggunaan Pada Hall Tiap Lantai

(Observasi Lapangan, 2017)

4) Aula pertemuan

Terletak pada lantai dasar bangunan blok $D$ dengan luas $\pm 90 \mathrm{~m}^{2}$ dan digunakan para warga penghuni sebagai wadah berkumpul penghuni rusun yang bersifat situasional seperti: posyandu, seminar dan penyuluhan dari pihak kelurahan, ulang tahun, syukuran warga. Area ini termasuk area semi private sehingga tidak bebas diakses selain para penghuni rusun, terkecuali bila terdapat acara yang diselenggarakan untuk publik umum. Daya tampung ruang ini mencapai 60-80 orang. Sehari-harinya area ini juga digunakan untuk menyimpan alat-alat pertemuan dan tempat parkir.

Beberapa jenis kegiatan yang biasa dilakukan dan intensitas penggunaan dalam seminggu pada aktivitas aula pertemuan dapat dilihat seperti yang tersaji pada Gambar 11 dari data hasil kuesioner responden berikut: 

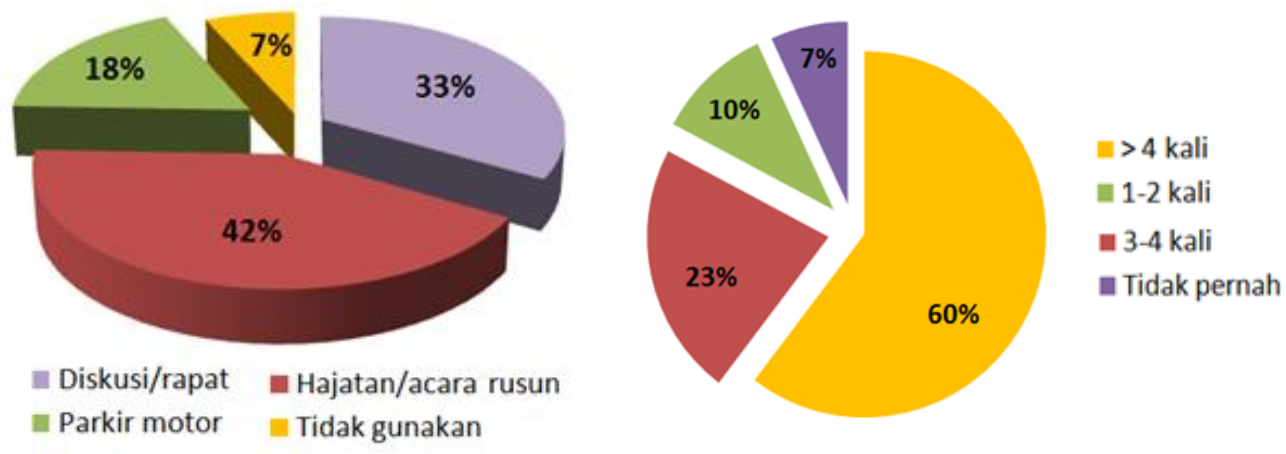

Gambar 11. Grafik Jenis Kegiatan dan Intensitas Penggunaan Pada Aula Pertemuan

(Observasi Lapangan, 2017)

5) Lapangan olahraga

Lapangan olahraga terletak pada lantai dasar sekitar taman aktif (berupa lapangan basket) dan diantara massa bangunan blok $C$ dan blok $E$ (berupa lapangan voli-badminton) yang juga tempat parkir kendaraan. Ruang publik ini sering digunakan warga penghuni (anak-anak hingga remaja) pada pagi dan sore hari. Lapangan voli-badminton yang sehari-harinya digunakan sebagai tempat parkir kendaraan, bila terdapat acara seremonial tertentu area ini dapat difungsikan sebagai ruang serbaguna yang dapat menampung banyak aktivitas.

Beberapa jenis kegiatan yang biasa dilakukan dan intensitas penggunaan dalam seminggu pada aktivitas lapangan olahraga dapat dilihat seperti yang tersaji pada Gambar 12 dari data hasil kuesioner responden berikut:

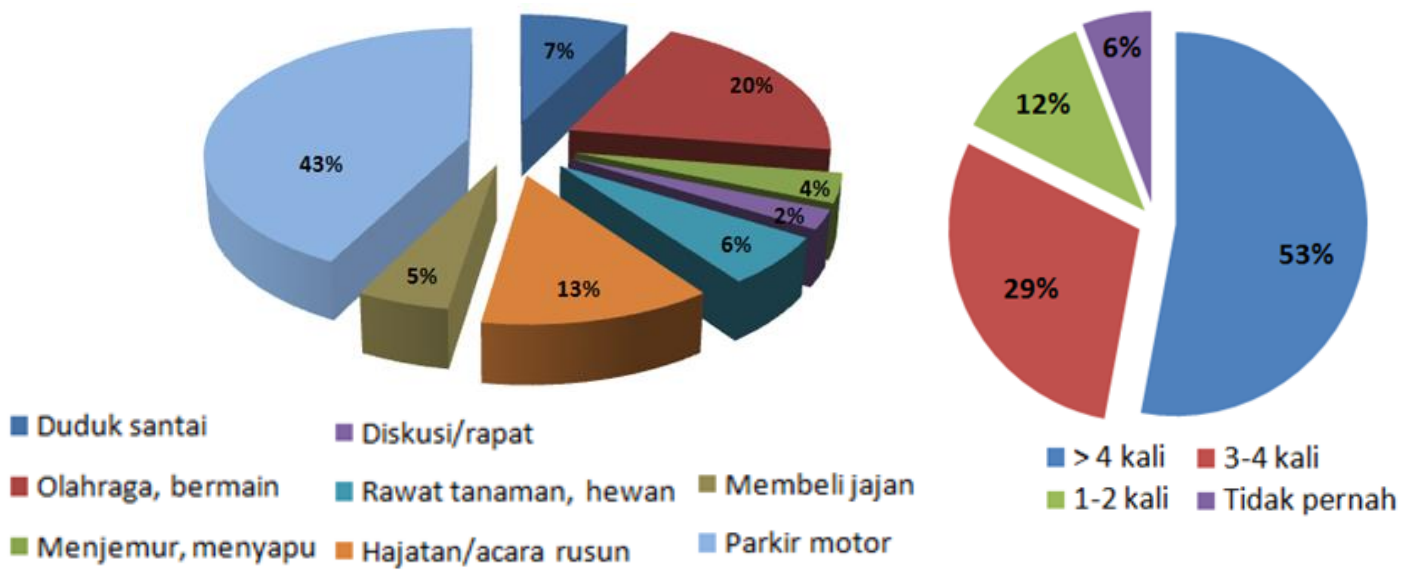

Gambar 12. Grafik Jenis Kegiatan dan Intensitas Penggunaan Pada Lapangan Olahraga

(Observasi Lapangan, 2017)

6) Lapangan parkir kendaraan

Terletak di lantai dasar lingkungan rusun yang mengakomodasi ruang parkir kendaraan penghuni rusun. Beberapa kantong parkir tersebar ditiap sudut kompleks. Area ini dapat berubah menjadi area serbaguna jika terdapat keperluan acara penghuni rusun yang bersifat situasional.

Para pengunjung yang beraktivitas (berbelanja, bekerja, berdagang) disekitar wilayah rusun terkadang ikut memarkirkan kendaraan motor mereka pada parkiran rusun. Ini dimanfaatkan oleh warga penghuni dengan menarik retribusi parkir yang dikumpulkan sebagai dana Pengurus Paguyuban Rumah Susun Pekunden (PPRSP). Dana ini biasa dipakai PPRSP untuk menambah biaya operasional perbaikan dan pemeliharaan fasilitas rusun. 
Beberapa jenis kegiatan yang biasa dilakukan dan intensitas penggunaan dalam seminggu pada aktivitas lapangan parkir dapat dilihat seperti yang tersaji pada Gambar 13 dari data hasil kuesioner responden berikut:
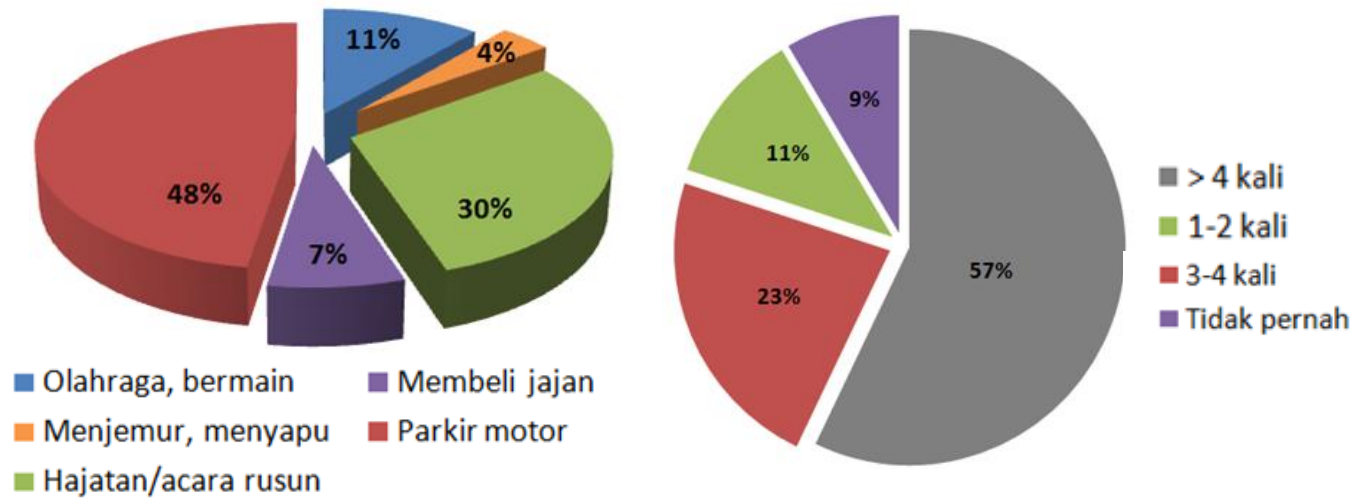

Gambar 13. Grafik Jenis Kegiatan dan Intensitas Penggunaan Pada Lapangan Parkir (Observasi Lapangan, 2017)

7) Taman aktif

Digunakan sebagai wadah interaksi sesama warga penghuni rusun dan juga masyarakat sekitar yang beraktivitas karena merupakan tempat terbuka umum. Dilengkapi dengan beberapa fasilitas seperti penerangan, bak sampah, sitting group, jalur kaki terapi lansia, wifi, dan juga vegetasi yang cukup banyak (lihat Gambar 14). Ada tanaman TOGA (Tanaman Obat Keluarga) yang dibudidayakan ibu PKK setempat. Disekitar taman aktif terkadang terdapat penjual/pedagang kaki lima yang memakai gerobak/sepeda berjualan pagi hingga malam hari.
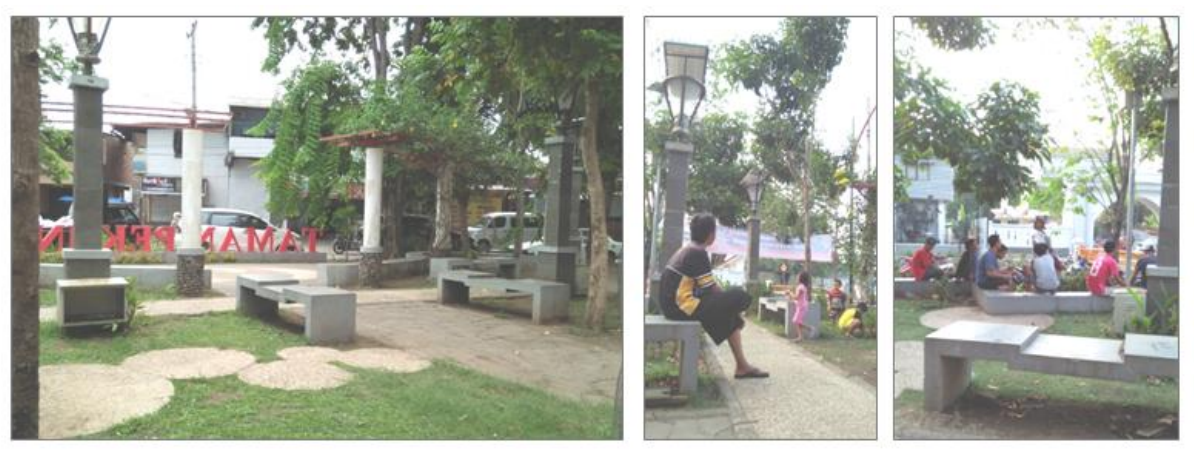

Gambar 14. Suasana Taman Aktif (Observasi Lapangan, 2017)

Beberapa jenis kegiatan yang biasa dilakukan dan intensitas penggunaan dalam seminggu pada aktivitas taman aktif dapat dilihat seperti yang tersaji pada Gambar 15 dari data hasil kuesioner responden berikut: 

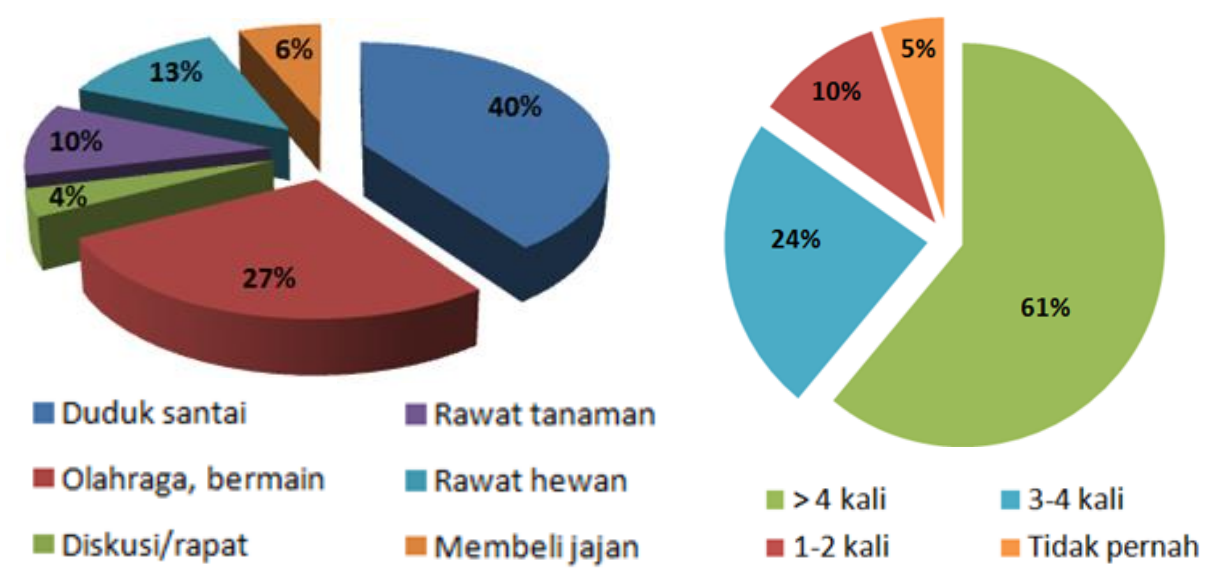

Gambar 15. Grafik Jenis Kegiatan dan Intensitas Penggunaan Pada Taman Aktif

(Observasi Lapangan, 2017)

8) Pasar dan kios sewa

Pasar dan kios terletak di lantai dasar bangunan rusun yang merupakan tempat terbuka umum (lihat Gambar 16) yang dapat dengan mudah diakses oleh penghuni rusun untuk melakukan kegiatan transaksi jual-beli keperluan sehari-hari. Para penghuni maupun pengunjung sekitar dapat saling berinteraksi bersama pada ruang publik ini dengan leluasa.
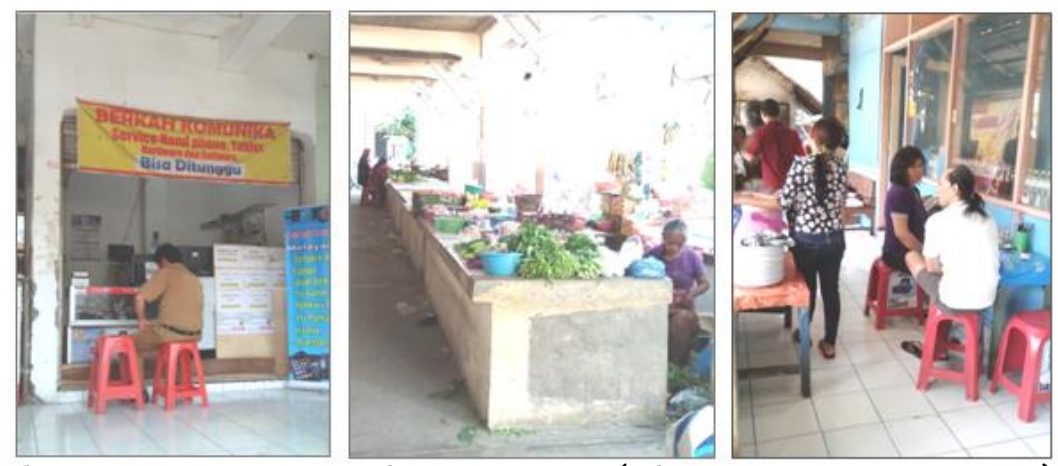

Gambar 16. Suasana Pasar dan Kios Sewa (Observasi Lapangan, 2017)

Para pelaku usaha merupakan warga setempat dan juga dari para pedagang sekitar lokasi. Berbagai varian kios usaha antara lain: kios kelontong, counter pulsa handphone, jasa fotocopy, rental komputer, servis alat-alat elektronik, salon, penjahit-bordir. Terdapat pula warung padang, warung tegal, warung prasmanan, serta angkringan. Lapak pasar terletak dilantai dasar blok $\mathrm{C}$ yang menyediakan berbagai keperluan dapur serta sayur-mayur. Area ini juga dilengkapi toilet umum.

Para pengunjung dari luar rusun sering kali juga datang dan ikut beraktivitas untuk sekedar berbelanja, mengobrol, maupun makan disini. Mereka kebanyakan merupakan pegawai kantor yang bekerja disekitar rusun, para karyawan mall, para pengunjung kantor/mall, maupun dari warga sekitar lingkungan rusun Pekunden.

Beberapa jenis kegiatan yang biasa dilakukan dan intensitas penggunaan dalam seminggu pada pasar dan kios sewa dapat dilihat seperti yang tersaji pada Gambar 17 dari data hasil kuesioner responden berikut: 

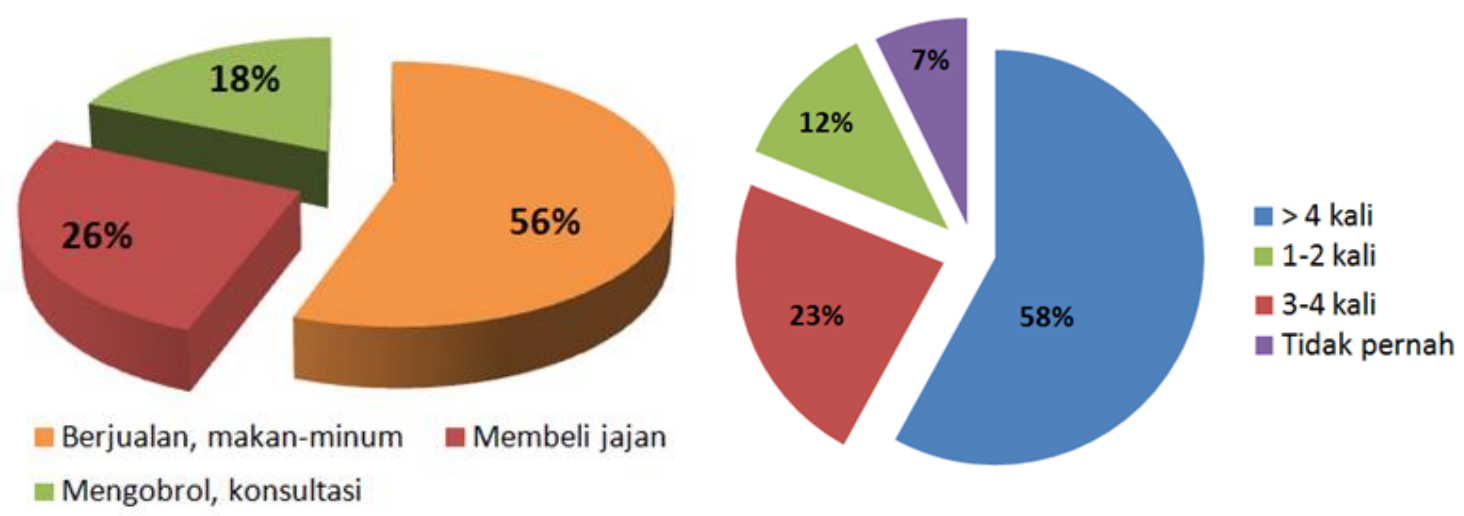

Gambar 17. Grafik Jenis Kegiatan dan Intensitas Penggunaan Pada Pasar dan Kios Sewa (Observasi Lapangan, 2017)

\section{KESIMPULAN}

Dari hasil analisis diatas diketahui bahwa penggunaan ruang publik sebagai wadah interaksi sosial pada ruang yang bersifat semi private dipengaruhi oleh beberapa faktor ketersediaan tempat duduk, tempat sampah, maupun ruang aksesibilitas yang cukup untuk beraktivitas bersama. Ketersediaan tempat duduk sebagai salah satu objek merupakan salah satu kriteria yang menarik untuk memberikan rasa nyaman dalam beraktivitas sehingga ruang publik tersebut akan lebih sering digunakan. Kemudian bila semakin tinggi partisipasi warga penghuni dalam mengikuti kegiatan perkumpulan, maka semakin sering pula ruang publik yang tersedia di rusun tersebut akan terpakai dan dimanfaatkan secara maksimal untuk berinteraksi bersama sesama penghuni rusun.

Untuk penggunaan ruang yang bersifat full public digunakan oleh para penghuni rusun bersama dengan masyarakat sekitar lingkungan rusun Pekunden terdapat kegiatan komersial (pasar \& kios sewa) yang tersedia pada lantai dasar cukup menarik minat untuk datang beraktivitas seperti transaksi jual-beli. Ketersediaan sarana rusun lainnya berupa taman aktif dan lapangan olahraga juga memberikan dampak positif bagi aktivitas warga pada ruang publik yang cukup optimal. Ketersediaan vegetasi yang mencukupi pada taman aktif banyak digunakan oleh warga untuk beraktivitas dengan nyaman. Pada pagi hingga sore hari taman serta lapangan olahraga dapat digunakan dengan maksimal. Ruang parkir yang tersedia didalam kompleks rusun dapat mengakomodasi dengan baik dan dapat mendatangkan keuntungan pendapatan dari tarif retribusi parkir. Ketika terdapat suatu acara rusun yang sifatnya situasional dapat menggunakan area ini untuk digunakan sebagai kepentingan bersama.

Dengan demikian hadirnya rusun Pekunden di lingkungan permukiman di tengah kota Semarang, dapat memberikan kebermanfaatan positif bagi lingkungan sekitarnya. Dapat membentuk serta menghasilkan suatu komunitas yang dinamis, karena dengan membentuk suatu komunitas yang baik dan ideal perlu rancangan suatu ruang publik yang dapat memberi keleluasaan kepada para penghuni untuk dapat saling berinteraksi satu sama lain. Pada akhirnya ruang publik yang tersedia dapat dimanfaatkan secara maksimal oleh penghuni dan juga masyarakat disekitarnya.

\section{PERNYATAAN RESMI}

Terima kasih diucapkan kepada Bapak dan Ibu Dosen Pengajar dan seluruh staf Program Magister Pembangunan Wilayah dan Kota (MPWK) Universitas Diponegoro Semarang, Dinas Tata Kota dan Perumahan Kota Semarang, serta kedua Orang tua, keluarga, dan rekan-rekan yang telah membantu menyelesaikan kegiatan penelitian ini hingga terselesaikan. 


\section{REFERENSI}

Carr, Stephen. (1992). Public Space. USA: Cambridge University Press

Darmawan, Edy. (2009). Ruang Publik dalam Arsitektur Kota. Badan Penerbit Undip

Darmiwati, Ratna. (2000). Studi Ruang Bersama dalam Rumah Susun. Dimensi Teknik Arsitektur Vol.28. Petra University

Farida, Nacuur. (2013). Effects of Outdoor Shared Space on Social Interaction. Frontiers of Architectural Research 2

Heimsath, Clovis. (1988). Arsitektur dari Segi Perilaku. Bandung: Intermatra

Jacinta, Francis. (2012). Creating Sense of Community: The Role of Public Space. Journal Environmental Psychology

Nazir, Mohammad. (2013). Metode Penelitian. Bogor: Ghalia Indonesia

Peraturan Pemerintah No.4 Tahun 1988 tentang Rumah Susun

Peraturan Daerah No.14 tahun 2011 tentang RTRW Kota Semarang 2011-2031

Prasetyo, Sigid. (2012). Perencanaan Rusunawa untuk Buruh di Kawasan Kumuh Kota Semarang.

Diakses: http://repository.unika.ac.id/view/creators/index.P.html

Semarang Dalam Angka 2016. Badan Pusat Statistik Kota Semarang

Sjafari. A. (2014). Kemiskinan dan Pemberdayaan Kelompok. Graha Ilmu. Yogyakarta

Sugiyono. (2010). Metodelogi Penelitian Kuantitatif, Kualitatif, dan R\&D. Bandung: Alfabeta

Suminar, El Yanno. (2016). Kampung Vertikal dengan Pendekatan Arsitektur Perilaku.

Diakses: https://eprints.uns.ac.id/24637/

Sutungpol, Niwan. (2013). Kampung Batik Vertikal di Panggungharjo Bantul.

Diakses: http://e-journal.uajy.ac.id/3875/1/0TA13011.pdf

UU Nomor 4 Tahun 1992 tentang Perumahan dan Permukiman

UU Nomor 20 tahun 2011 tentang Rumah Susun

Wellman, Barry and Leighton. 1979. Networks, Neighborhoods, and Communities. University of Toronto 